\title{
Quality of school life in Turkey, Finland and South Korea
}

\author{
Ayşe Elitok Kesici ${ }^{1}$, Veysel Karani Ceylan² \\ ${ }^{1}$ Department of Curriculum and Instruction, School of Education, Aydın Adnan Menderes University, Turkey \\ ${ }^{2}$ Milas District National Education Directorate, Turkey
}

\begin{tabular}{l}
\hline \hline Article Info \\
\hline Article history: \\
Received Jan 13, 2020 \\
Revised Feb 20, 2020 \\
Accepted Feb 29, 2020
\end{tabular}

Keywords:

Quality of school life

Comparative education

Literature review

\begin{abstract}
This study was aimed to compare the major studies conducted on the quality of school life in Turkey, Finland and South Korea. The study focuses on which dimensions of quality of school life research in these three countries were examined, their participants, school levels and research methods. This research is in the literature review model. In this context, data were obtained by scanning the related books, theses and articles. In the research, document analysis technique of qualitative research method was used to collect data. Based on the research findings, it is seen that research studies have been conducted in Finland to establish the theoretical framework for conceptualization of the subject. Qualitative, quantitative and mixed methods were used in research studies conducted in South Korea. In the research conducted in three countries, the concept of self, bullying, implicit program, gender, socio-economic level, classmate, teacher and family support, self-efficacy, music, living environment, self and teacher-learner relationship have been determined to affect quality of school life. In the research studies conducted in Turkey, levels of quality of school life were detected, whereas in the research studies conducted in South Korea, the importance of traditional values of Confucius doctrine were focused on.
\end{abstract}

This is an open access article under the CC BY-SA license.

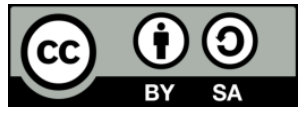

\section{Corresponding Author:}

Ayşe Elitok Kesici,

Department of Curriculum and Instruction, School of Education,

Aydın Adnan Menderes University, 09100, Turkey.

Email: aelitok@adu.edu.tr

\section{INTRODUCTION}

Human beings want to pursue a quality living throughout their life. A quality living is the most important factor for an individual to live a happy, safe and satisfying life. When we consider human as a bio-psycho-social being, we have to accept that throughout their life, people have interests, needs and expectations in these areas. Achieving a standard of living that takes these needs into consideration enables an individual to live a humanly life. Meeting needs in the school environment improves the quality of school life (QSL) [1, 2]. In today's schools, it is seen that the importance given to the quality of school life has begun to increase in order to increase the emotional commitment of individuals as well as their academic success. Quality of school life indicates that schools should include various social activities such as culture, art, sports and literature along with academic satisfaction. On the other hand, quality of school life is also related to the school's competence in terms of accommodation, library and meeting various human needs. In the early 1990's, schools focused only on learners' cognitive and intellectual development [3]. However, there was also a growing interest in the social purpose of schooling [4]. While evaluating the outcomes in our education life, it is seen that especially academic achievements in cognitive domain are taken into consideration and gains in the affective domain are ignored. As stated by the researches in the field, quality of school life that affects academic success closely is the primarily ignored affective areas. 
Schools are institutions that are responsible for the social development of learners as well as their academic development $[5,6]$. It is stated that the definition of "what is a good school?" is mostly discussed in terms of academic success, and the personality, spiritual, emotional and social skills that learners gain are not considered $[7,8]$.

In the literature, many studies examining the effects of quality of school life can be found in the studies conducted on the subject [1,9-11]. When these studies are examined briefly; we can see [12-15], examining the quality of school life according to some variables (bullying, empathy development, etc.) and research titles such as relationship of quality of school life with the implicit curriculum, determination of quality of school life in high schools, concept of self and quality of school life and developing a scale on this subject. The absence of a study in the literature comparing the quality of school life in other countries makes this research important. Comparative education is a discipline that helps define the similarities and differences of two or more education systems in different cultures and different countries, explains phenomena that look similar, and brings useful proposals about ways to educate people [16-18]. Comparative education is a complex field of study that helps to understand education and is closely related to disciplines such as psychology, linguistics, economics, sociology, history and anthropology [19, 20]. In the adoption of comparative education in this study as an approach, the concept of quality of school life being in a structure not limited to school and the basic structures such as society, culture and history analyzed more easily with comparative education have been effective.

There is consensus among parents, teachers, administrators, and learners that schools should be places that maximize children's learning and where learners feel happy and safe and satisfied with their teachers and learning. A happy school environment also increases academic success. Because of the important effects of quality of school life on the academic success of learners and the other outcomes of education, a lot of research has been done by educators about the well-being of learners at school. However, in the studies conducted, the comparison of quality of school life and its sub-dimensions in different countries through inter country studies were not emphasized. Therefore, it was aimed to compare the major studies conducted on the quality of school life in Turkey, Finland and South Korea in this research. The study focuses on which dimensions of quality of school life research in these three countries were examined, their participants, school levels and research methods.

\section{RESEARCH METHOD}

The current research is in the comparative education structure. Bray and Thomas method, one of the methods used in comparative education, was used in the research. Bray and Thomas [21] have developed a method that can be used to classify comparative studies in education by level and type. The method, which can be considered as a breakdown of the topics examined in comparisons, is depicted as a cube shape and is an analytical tool for the comparative analysis of the questions of who, what and where [22].In this study, Turkey, Finland and South Korea were selected in response to question "who", quality of school life can be answer in response to the question "what" and document analysis environment can be an answer to the question "where". In this research, "literature review method" was used to examine QSL studies. In this method, written documents about the phenomenon or events discussed in the research are analyzed [23]. Literature reviews are used in educational research to reveal important links and forms in the literature and to guide future research and practices [24]. In this context, related articles, books and theses were scanned and data were obtained. While analyzing the documents in the research, primary sources were tried to be accessed by examining the current databases and as a resource, websites of the ministries of education of the relevant countries, virtual libraries, websites of the universities, reports issued by the OECD and the National Education and Economy Center for the relevant countries (National Center on Education and the Economy NCEE) and databases of scientific journals were used. The keywords used when researching the concept of quality of school life in the relevant countries were determined as "school satisfaction", "quality of school life", "school attachment", "school life satisfaction". Content analysis of the resources reached was made in line with these keywords. In order to collect data in the study, a search was made by entering the keyword "university quality of life" from databases such as EBSCOHost, ERIC and ISI Web of Science and then from the Google Scholar search engine. Full text articles were reached as a result of this search. In addition, various books and theses on the subject have been used. In this study, 34 full text journal articles were accessed, 9 books, 6 theses and 1 paper were examined. In this context, 50 sources have been reached. According to Karasar [25, 26] scans are research approaches that try to describe a situation as it is in the past or present. In this study, secondary data sources about QSL published in the past were investigated. With this aspect, the study is in the literature review model. According to Erkuş [27], literature reviews are; to examine and analyze the works that have been done and accumulated in a certain area. In this method, the advantages and disadvantages of the studies are critically handled and important inferences are made for new studies. 
In this working process, a three-step method was followed [28]:

a. Determination of scanning method and selection criteria: $\mathrm{n}$ order to examine the studies performed in the research process and to clearly determine the characteristics and results of QSL research, quantitative, qualitative and mixed method researches were examined. Their appearance in refereed journals using these research designs was of primary concern.

b. Scanning process: In this stage, firstly, queries with keywords were conducted in databases.

c. Analysis process: Similar and different findings of articles were summarized.

\section{RESULTS AND DISCUSSION}

As a result of the literature review carried out in the findings part of the research, studies related to quality of school life in related countries were included and a general analysis of these studies was made. The Table 1 contains the researches done in the countries.

Table 1. Researches on quality of school life in Turkey, Finland and South Korea

\begin{tabular}{|c|c|c|}
\hline Countries & Researchers & Research Name \\
\hline \multirow{4}{*}{ Turkey } & Sarı \& Cenkseven [29] & Quality of school life and self-concept among elementary school learners \\
\hline & & School In Borders Of Adana Province With Respect To The Quality Of School Life \\
\hline & Elitok Kesici \& & Level Of Quality of School Life In Secondary Education Institutions And Implicit \\
\hline & Türkoğlu [31] & $\begin{array}{l}\text { Behaviours Exhibited By Teachers Of Secondary Education In Intraclass } \\
\text { Communication }\end{array}$ \\
\hline \multirow[b]{3}{*}{ Finland } & Tangen [32] & $\begin{array}{l}\text { Conceptualising quality of school life from pupils' perspectives: a four-dimensional } \\
\text { model }\end{array}$ \\
\hline & $\begin{array}{l}\text { Danielsen, Samdal, } \\
\text { Hetland \& Wold [33] }\end{array}$ & School-Related Social Support and Learners' Perceived Life Satisfaction \\
\hline & Eerola \& Eerola [34] & Extended music education enhances the quality of school life \\
\hline \multirow{6}{*}{ South Korea } & $\begin{array}{l}\text { Lee, Fraser \& } \\
\text { Fisher [37] }\end{array}$ & Teacher-Learner Interactions in Korean High School Science Classrooms \\
\hline & Park [38] & Life Satisfaction Among Korean Children and Youth \\
\hline & & A Developmental Perspective \\
\hline & Kim \& Kim [39] & Social Relations and School Life Satisfaction in South Korea \\
\hline & Jeong, Lee \& Cho, [40] & Education decentralization, school resources, and learner outcomes in Korea \\
\hline & Deters [41] & $\begin{array}{l}\text { Comparing the Experiences and Needs of Postsecondary International Learners from } \\
\text { China and South Korea }\end{array}$ \\
\hline
\end{tabular}

The research of Sar1 and Cenkseven [29] was carried out on 493 learners (235 girls, 258 boys) attending the $4^{\text {th }}, 5^{\text {th }}, 6^{\text {th }}$ and $7^{\text {th }}$ grades of four primary schools. Gradual regression analysis was used to analyze the data collected using the "Quality of school life Scale" (QSLS) and "Piers Harris Self-Concept Scale in Children". As a result of the analysis of the data, it was determined that all dimensions of the "SelfConcept Scale in Children" show significant relationships with the quality of school life. This research was conducted by quantitative method.

The participants of İnal and Sadik's [30] research are 36 teachers and 643 learners studying in these schools. Quantitative method was used in the research. As a result of the research, it was seen that teachers 'and learners' perceptions regarding Regional Primary Boarding Schools' life quality were almost similar, and both groups perceived their schools' life quality positively, a little above the middle level. The most positive perceptions of teachers and learners about the quality of school life of RPBS were towards their own status and the most negative perceptions were towards school management, and it was determined that the perceptions of female learners and female teachers were more positive. In the research, where teachers perceived learners more positively and learners perceived school management more positively than teachers, it was observed that teachers perceived the school's life quality higher in general.

The participants of the study of Pelendicioğlu [14] were 859 high school learners in $9^{\text {th }}, 10^{\text {th }}$ and $11^{\text {th }}$ grades. Quality of school life scores were found to be higher in those who did not participate in bullying. The data of the research were collected by quantitative method. 
A total of 969 learners studying in 18 high schools participated in the study of Elitok Kesici and Türkoğlu [31]. According to the research findings, it can be said that the learners perceive the life quality in their schools just above the middle. When the findings obtained from the observations were evaluated, it was observed that the positive behaviors of the teachers increased as the quality of high school life increased in the classroom communication within the scope of the implicit program. The mixed method was used in this research.

The research of Tunç and Beşaltı [15] was carried out on $6^{\text {th }}, 7^{\text {th }}$ and $8^{\text {th }}$ grade learners $(n=469)$. As a result of the research, in terms of gender; there were significant differences between the scores obtained from the "communication between learners" and "teacher dimension" subscales of the Quality of School Life Scale; according to parents' living together or separately, between the scores they obtained from the "teacher dimension" subscale; according to their perceived socio-economic levels, between the scores obtained from the sub-scales of "status", "school management", "feelings about the school" and "teacher dimension" and between the scores obtained from the total of the scale; according to the learners' perception of themselves in terms of school success, between the scores obtained from the "status", "school management" and "feelings about school" subscales. In this research, quantitative method was used.

This paper presents a four-dimensional, dynamic model of pupils' subjective quality of school life. The model is based on the author's and colleagues' studies of experiences and perspectives of pupils in regular schools who have been assessed as having "special educational needs". The conceptualization of quality of school life proposed here is aimed at serving as a "direction indicator" for where to look and how to listen to pupils, not at giving detailed definitions or prescriptions. The model may also serve as a tool for studying and discussing quality of school life in terms of overall educational goals as well as schooling conditions that are being offered by national school systems and individual schools. A few aspects of relations between subjective quality of school life and "objective" conditions, which are very complex, are discussed. It is concluded that the experiences and perspectives of pupils, especially of those pupils whose voices are seldom heard, can make a powerful contribution to developing a better understanding of how equality, inclusion and quality of school life can be achieved [32].

In another study conducted in Finland titled "Life satisfaction perceived by learners and social support about school" was brought to the literature by Danielsen, Samdal, Hetland and Wold [33]. The study was designed as a method of path analysis and according to the proposed model; the relationship between the concepts of classmate support, teacher support, family support on school satisfaction, school skills and their general self-efficacy and learners' life satisfaction were examined. The sample of the study consisted of 13-year-old learners $(\mathrm{N}=1,736)$ and 15 -year-old learners $(\mathrm{N}=1,622)$ by selecting 3358 learners according to the systematic sampling method. Different scales were used to measure 7 items as a data collection tool.

Independent t-test was used to determine whether there was a significant difference in the findings of the study according to age and gender. At both age levels, men have claimed higher life satisfaction, self-efficacy and academic skills. On the other hand, girls only have higher scores on school satisfaction. According to the ages, 15-year-olds were found to be significantly different in both genders, with the exception of academic skills and self-efficacy. It was determined that there is a high interaction $\left(\mathrm{R}^{2}=.55 ; \mathrm{p}<.05\right)$ between teacher support and school satisfaction. Family and classmate support are other variables that directly affect learners' life satisfaction. In addition, while school satisfaction directly affects life satisfaction, academic skills indirectly affect life satisfaction through general self-efficacy.

Eerola and Eerola's research [34] "The claim of whether music education can create social benefits in the school environment" was tested in 10 Finnish schools with an extended music curricular class and control classes. The quality of school life (QSL) was assessed by a representative sample $(\mathrm{N}=735)$ of pupils at years 3 and 6 (9- and 12-years-olds). The results showed that extended music education enhances the QSL, particularly in areas related to general satisfaction about the school and a sense of achievement and opportunity for learners. Differences related to the schools and gender did not account for the results. A follow-up study examined whether the increase in critical QSL variables was related to music. This analysis utilized data from other classes $(\mathrm{N}=98)$ with an extended curriculum (sports and visual arts). These classes did not confer similar benefits. Overall, the results imply that extended music education has a positive effect on the social aspects of schooling.

Park and Lee's [35] study investigated the influence of between-school differences in participative school climate, time and money as learning supports, frequency of teacher appraisal, school SES, and number of teachers on individual teacher's collegial interaction. Nationally representative data for 8869 teachers in 551 lower secondary schools in England, Finland, South Korea, and the USA were analyzed. In all four countries, a participative school climate was positively associated with teacher collegial interaction, while support in the form of extra compensation did not have a significant effect on teacher collegial interaction. The influence of other school-level features was not consistent across countries. 
Another study on comparing the quality of school life of adults in Finland and Korea, "Is the PISA model people happy at school?" was conducted by Yoon and Jarvinen [36]. According to the results of the PISA (Program for International Learner Assessment) conducted regularly among OECD countries, a study was conducted on the quality of life of schools across the two successful sample countries. In this study, school quality of life was discussed under 3 main titles and these titles were determined as General Satisfaction, Peer Relations and Learner-Teacher Relations.

In this study, the education system of Finnish and Korean people was tried to be analyzed both in social and educational terms by the following arguments. The first of these variables is to examine the difference between nations and regions or socio-cultures based on the individual social, cultural and historical context of each country. In comparative education research, it is generally considered in terms of cognitive-affective learning outcomes in east-west, school environment. The second variable, while cognitive learning is more important in research in the school environment, the affective domain like school life is ignored. This study sheds light on this area as content.

The aim of this study is to examine the school life quality, teacher-learner interaction, general satisfaction and peer relationship of learners of two different countries, which are successful according to PISA results in 2012 in terms of their cultural, institutional and historical aspects. Firstly, PISA results, measurement of past performances applied to learners and forms with school-related factors and interview forms with learners (such as whether they are happy at school and what causes if they are unhappy) were used in the study.8829 learners at the age of 15 from Finland and 5033 learners from South Korea participated in the study. These learners are the learners who have entered PISA.

In questions about happiness in school; Northern countries gave higher positive answers to almost all items compared to eastern countries. In statistical studies, there was a significant difference according to Bonferroni and z-test. Compared to the OECD average, it is seen that eastern countries have a lower average. Considering the happiness variance of children in the PISA model in Finnish and Korean schools, it is seen that it is below the OECD average. Korea has achieved values below the OECD average in terms of both satisfaction in teacher learner interaction and satisfaction in peer interaction. It has been observed that Finnish learners are more satisfied with school life quality and peer relationships than South Korean learners. In the studies conducted by Bronfenbrenner [42] and Hofstede [43], it was concluded that Korean individuals are more masculine, long-term thinking and fleeing entertainment due to their future anxiety.

As the limitation of the study, the researcher stated that the statistical values obtained from a standard scale could not be fully sufficient in explaining an abstract concept such as quality of school life. In this regard, the views and experiences of Chinese and Korean learners on school quality of life could not be fully reflected in the study.

In another study on learner-teacher interaction in Korea; Lee, Fraser and Fisher [37] translated the scale of teacher interaction at a high school level into Korean and applied it to 439 learners from different branches. The main aim of the study is to examine the environments of science classes at high school level in Korea in three different ways as the degree of application of constructivism, the structure of learner-teacher interaction and the learning environment of laboratory classes. In the study, observations and interviews with teachers and learners were held in three classes. In the findings of the study, the teachers who guided that the interaction in the science class is like the old-young interaction in the society stated that there is an interaction in the form of learners who follow the rules. In addition, it was determined that they showed more special communication and interaction skills with some teachers and this difference is thought to be due to the fact that the personal characteristics of teachers coincide with the characteristic of a curriculum (eg. curriculum, expectation for learners in that curriculum). The study gave an insight into the current state of science classes in high schools in Korea.

A cross-sectional study of developmental differences and similarities in the levels and correlates of life satisfaction was conducted with 716 South Korean learners in elementary, middle and high school. With age, global and domain-specific life satisfaction (with family, school, living environment and self) decreased; satisfaction with friends did not change with age. The family domain was an important predictor of global life satisfaction of Korean learners of all ages. The importance of the self-domain to global life satisfaction increased substantially with age to emerge as the most important contributor for global life satisfaction among high school learners. School satisfaction was consistently important for Korean learners' global life satisfaction across all ages, although its relative importance decreased with age. These findings were discussed with respect to the development of concerns and interests among children and adolescents and in terms of Korean cultural values based on Confucianism [38].

This study pays special attention to adolescents who are at the critical stage of social, cognitive and emotional development and their satisfaction with school life which is important for their educational experience and adult life. The purpose of this study is to examine how learners' relationships with friends, teachers and parents are associated with their school life satisfaction. We conducted hierarchical linear 
modeling with nationally representative data on 3,790 high school seniors in the consideration of different school types (general and vocational high schools) reflecting the contextual characteristics of South Korean education system. Our findings show that all those relations are associated with school life satisfaction and that some distinctive dimensions of each relation matter for learners' school life satisfaction. In particular, teacher-learner relationship was found to shape learners' satisfaction with school life both at individual and school level. In spite of several limitations, the broad investigation of learners' social relations provided a policy implication for improving adolescents' satisfaction with their school lives [39].

Government decentralization is in worldwide use for education reforms. It takes different forms across countries from political and fiscal perspectives. It is a unique feature that the governance of Korea is politically decentralized, but it remains fiscally federalized. In this article, we utilized both political and fiscal perspectives to evaluate her decentralization by school resources and learner outcomes. After analyzing the panel data, we find that fiscal decentralization is positively related to learner outcomes. In contrast, we find little evidence on any relationship between political decentralization, school resources, and learner outcomes. Lastly, we draw useful policy implications for developing countries whose decentralization moves like Korea [40].

\section{DISCUSSION}

In the study titled "School Life Quality in Finnish and Swedish Spoken Schools" by Linakyla and Brunell [44], the quality of school life between two Finnish-speaking and two Swedish-speaking schools was tried to be determined in the school environment. 1379 students from the $8^{\text {th }}$ grade Finnish-speaking schools and despite the fact that Swedish speakers were not fully specified in the sample, about 4697 people participated in the study on a national scale. In the research, a 29-item scale developed by Williams and Batten in 1981 [45] including the sub-dimensions of general satisfaction, negative emotions, learning excitement, personality development and status was used. According to the research results; in the profile of Finnish and Swedish speaking schools, many similarities have been detected as well as some differences. Quality of school life has the same level of effectiveness in both school systems. When we look at the topics observed in the study, school satisfaction, negative reaction to the school, open mindedness and social identity of the students were examined. In the study, the fact that the families of the students who speak Swedish are wealthier caused some differences. This situation is effective on students' motivation, their status in the classroom and their quality of school life. In addition, the study has a comparative study feature and data at the end of the study were compared with a total of 24732 students from Germany and Nordic countries that are Norway, Denmark and Iceland.

When the research studies related to the quality of school life in Turkey, Finland and South Korea are evaluated in general, it was determined that the studies in Turkey were performed on teachers and primary and secondary school students [46]. Studies conducted in Finland have been conducted with primary, secondary and high school students. Studies conducted in South Korea are at primary, secondary, high school and university level. Quantitative and qualitative methods were used in studies in Turkey, and the quality of school life model, path analysis model and quantitative research methods were used in the studies conducted in Finland. In Finland, it is seen that research studies have been done to establish a theoretical framework for conceptualization of the subject. Qualitative, quantitative and mixed methods were used in studies conducted in South Korea. In the research studies conducted in three countries, the concept of self, bullying, implicit program, gender, parents living together or separately, socio-economic level, classmate support, teacher support, family support, self-efficacy, music, living environment, self and teacher- student relationship have been found to affect the quality of school life. In the studies conducted in Turkey, while the levels of quality of school life are determined, the importance of traditional values of the Confucius doctrine is emphasized in studies conducted in South Korea. In South Korea, it was determined that teachers raise students according to traditional rules. In addition, the fact that the education system has a central structure in South Korea affects students' school satisfaction positively.

Research studies conducted in Finland can contribute to the formation of a theoretical framework in a scientific sense. Studies supporting the theoretical framework may be included in quality of school life research studies in Turkey and South Korea. In all three countries, quality of school life research studies that include all learning stages from kindergarten to doctorate level can be included. In future researches, the relationship between students' quality of life and many concepts that affect student's perception can be examined. Determining how QSL, which consists of factors affecting students' school achievements and motivation and explains the environment in which students can be happy in all aspects of the school, is perceived by students is of great importance for the effective development of education and training activities and the development of students and social development. In future researches, education systems of countries 
can be compared in terms of quality of school life by using mixed method. Thus, applications of education systems with positive characteristics can be taken as example by education systems of other countries.

\section{CONCLUSION}

In the research conducted in Turkey, a significant relationship has been found between the concept of self of children and adults, school bullying and quality of school life. The methods used in these studies were quantitative, qualitative and mixed methods. Researches were conducted at secondary and high school level. Attention was drawn to the relationship between the implicit program and quality of school life. Another research was conducted with teachers and students in regional boarding schools and it was found that both groups' perceptions of school quality of life a little above the middle level. The most positive perceptions of teachers and students about the quality of school life were directed towards their status and the most negative perceptions were towards the school administration. It has been determined that the perceptions of female learners and female teachers are more positive in terms of school life quality. It was determined that personal variables such as gender of the students, whether their parents live together or separately, and the socio-economic level significantly differentiate their school life quality scores.

In the research carried out in Finland, a four-dimensional school quality of life model was created and this research aimed to serve the conceptualization of the subject. This model has a leading feature for educational systems. The model can also serve as a tool to study and discuss school quality of life. Several aspects of the relationship between the subjective quality of school life and the very complex "objective" conditions are being discussed. It has been determined that a better understanding of how equality, participation and quality can be achieved in school life can make a strong contribution by the help of this model.

In another study conducted in Finland; the study was designed as a method of path analysis, and according to the proposed model; the relationship between the concepts of classmate support, teacher support and family support, school satisfaction, general self-efficacy about school skills, music and students' life satisfaction were examined. Research studies in Finland were conducted with primary, secondary and high school students. Quantitative research method was used. School satisfaction of female students is higher. A high relationship was determined between academic skills, self-efficacy, classroom support, teacher support, family support and school satisfaction. Family and classmate support are variables that directly affect students' life satisfaction. Music and participatory school environment positively affect the quality of school life.

Research studies conducted in South Korea are at primary, secondary, high school and university level. In a research, relationships between family, school, living environment and self and quality of school life were determined. The importance of traditional values of Confucius doctrine is emphasized. Qualitative, quantitative and mixed methods were used in the studies. It has been determined that teachers raise students according to traditional rules. The study gave a point of view about the current state of science classes of high schools in Korea. In particular, it was found that teacher-student relationship shapes students' satisfaction with school life at both individual and school level. Therefore, it requires an increase in the qualifications of teachers. The fact that the education system has a central structure affects school satisfaction of students positively.

\section{REFERENCES}

[1] A. Elitok Kesici, and B. Çavuş, "University life quality and impact areas," Universal Journal of Educational Research, vol. 7, no. 6, pp. 1376-1386, 2019.

[2] A. Durmaz, "Liselerde okul yasam kalitesi (Kırklareli İli Örneği)," Yüksek Lisans Tezi, Trakya Üniversitesi Sosyal Bilimler Enstitüsü, Edirne, 2008.

[3] D. Tyack, \& L. Cuban, "Tinkering toward Utopia: A century of public school reform,"Cambridge: Harvard University Press, 1997.

[4] J.A. Baker,"The social context of school satisfaction among urban, low-income, African American students," School Psychology Quarterly, vol. 13, no. 1, pp. 25-44, 1998.

[5] G. N. Marks, "Attitudes to school life: Their influences and their effects on achievement and leaving school," Australian Council For Educational Research Ltd, Australia, 1998.

[6] M. Özdemir, "Üniversite öğrencilerinin okul yaşamının niteliğine ilişkin algılarının cinsiyet ve fakülte değişkenlerine göre incelenmesi," Kuram ve Uygulamada Eğitim Yönetimi, vol. 18, no. 2, pp. 225-242, 2012.

[7] R. Weston, "Quality of school life in government, Catholic and other private schools," Family Matters, Winter, 50, $5661,1998$. 
[8] H.Aldinç, B. Aytar, M. E. Demetçi, A. E. Seçen, A. Şahin \& H. Yılmaz,” Ankara ilinde seçilen birinci basamak sağlik kuruluşlarına başvuran 18 yaş ve üzeri kişilerin medikososyal özelliklerine göre yaşam kalitelerinin karşılaştırılması," Master'sThesis, Gazi Üniversitesi, Ankara, 2004.

[9] N. Ciftci Aridag, M. Aydın and R. Aydın, "Undergraduate Students' Satisfaction Levels on the Quality of Faculty Life," Eurasian Journal of Educational Research, vol. 73, pp. 1-18, 2018.

[10] C. Toraman, B. Ayçiçek, "An investigation of the relationships between attachment levels to school and the variables of the perception of school life quality and peer pressure among high school students," Journal of Education and Training Studies," vol. 7, no. 1, Jan 2019.

[11] M. Sarı, "Okul yaşamının değerlendirilmesi: okul yaşam kalitesi ölçeğinin geçerlik ve güvenirliği," Hacettepe Üniversitesi, Eğitim Fakültesi Dergisi, vol. 42, pp. 344-355, 2012.

[12] M. Sarı, "Demokratik değerlerin kazanımı surecinde örtük program: Düşük ve yüksek okul yaşam kalitesine sahip iki ilköğretim okulunda nitel bir çalışma," Yayınlanmamış Doktora Tezi, Çukurova Üniversitesi, Sosyal Bilimsel Enstitüsü, Adana, 2007.

[13] A. Elitok-Kesici, "Ortaöğretim öğretmenlerinin sınıf içi iletişimde kullandıkları örtük programın özellikleri," (Doktora Tezi), Adnan Menderes Üniversitesi Sosyal Bilimler Enstitüsü, Aydın.2010.

[14] B. Pelendicioğlu, "Lise ögrencilerinde zorbalık olgusunun okul yasam kalitesi ve empati değişkenleri bakımından incelenmesi," Yüksek Lisans Tezi, Sosyal Bilimler Enstitüsü, Abant İzzet Baysal Üniversitesi. 2011.

[15] E. Tunç and M. Beşaltı, "Okul Yaşam kalitesinin bazı değişkenlere göre incelenmesi," Turkish Journal of Education, vol. 3, no. 4, pp. 28-39, DOI: 10.19128/turje.181090, 2014.

[16] A. Türkoğlu, "Fransa, İsveç ve Romanya Eğitim Sistemleri," Ankara: Ankara Üniversitesi Eğitim Bilimleri Yayınları, no. 121, 1983

[17] H.M. Eriş. "Üniversite Öğrencilerinin yaşam kalitesi düzeylerinin bazı değişkenlere göre incelenmesi,” (Yüksek lisansTezi), Hacettepe Üniversitesi Sosyal.BilimlerEnstitüsü, Ankara, 2012.

[18] Ö. Demirel, "Ĕgitim Sözlüğ̈̈ (5. Baskl)," Ankara, Pegem Akademi Yayıncılık, 2012.

[19] G. Philip Altbach and P. Gail Kelly, "New approach to comparative education," Chicago, University of Chicago Press, 1986.

[20] T. Argon \& M. İsmetoğlu, "Öğrencilerin lise yaşam kalitesi algıları ile okula bağl1lık düzeyleri arasındaki ilişki," Ĕ̆itim ve Öğretim Araştırmaları Dergisi, vol. 5, no. 1, pp. 238-249, DOI: 10.17719/jisr.2017.1799, 2016.

[21] M. Bray, and R.M. Thomas, "Levels of comparison in educational studies: Different insights from different literatures and the value of multilevel analysis," Harvard Educational Review, vol. 65, no. 3, pp. 472-489, 1995.

[22] İ.Yüksel and M. Sağlam, "Karşılaştırmalı eğitim yansımaları," Pegem akademi, Ankara. 2012.

[23] A. Yıldırım, ve H. Şimşek, "Sosyal bilimlerde nitel araştırma yöntemleri,” (Güncelleştirilmiş ve geliştirilmiş 11. baskı), Ankara, Seçkin Yayıncılık, 2018.

[24] D. D. Minner, A. J. Levy, \& J. Century, "Inquiry-based science instruction - what is it and does it matter? Results from a research synthesis years 1984 to 2002," Journal of Research in Science Teaching, vol. 47, pp. 474-496, doi:10.1002/tea.20347, 2010.

[25] N. Karasar, "Bilimsel Araştırma Yöntemleri," Nobel Yayıncılık, Ankara, 2019.

[26] L. Cohen, L. Manion, \& K. Morrison, "Research methods in education," Taylor\&Francis elibrary. [Adobe Digital Version], 2005.

[27] A. Erkuş, "Davranış bilimleri için bilimsel araştırma süreci,” Seçkin Yayıncılık, Ankara.2017.

[28] Z. Karaçam, "Sistematik derleme metodolojisi: Sistematik derleme hazırlamak için bir rehber," Dokuz Eylül Üniversitesi Hemşirelik Yüksekokulu Elektronik Dergisi, vol. 6, no. 1, pp. 26-33, 2013.

[29] M. Sarı ve F. Cenkseven, "İlköğretim öğrencilerinde okul yaşam kalitesi ve benlik kavramı," Uluslararası İnsan Bilimleri Dergisi, cilt. 5, Say1. 2, pp. 1-16, 2008.

[30] U. İnal ve F. Sadik, "Adana ili sinirlari içerisindeki yatili ilköğretim bölge okullarinda bulunan öğrenci ve öğretmenlerin okul yaşam kalitesi algilarinin incelenmesi," Çukurova Üniversitesi Sosyal Bilimler Enstitüsü Dergisi, vol. 20, no. 2, pp. 243-258, 2011.

[31] A. Elitok Kesici, \& A. Türkoğlu, "Ortaöğretim kurumlarının okul yaşam kalitesi düzeyi ve ortaöğretim öğretmenlerinin sınıf içi iletişimde kullandıkları örtük davranışlar," Pamukkale Üniversitesi Eğitim Fakültesi Dergisi, vol. 31, no. 1, pp. 149-162, 2012.

[32] R. Tangen, "Conceptualising quality of school life from pupils' perspectives: A four dimensional model," International Journal of Inclusive Education, vol. 13, no. 8, pp. 829-844, 2009.

[33] A. Danielsen, O. Samdal, J. Hetland, and B. Wold, "School-related social support and students'perceived life satisfaction," The Journal of Educational Research, vol. 102, no. 4, pp. 303-320, DOI: 10.3200/JOER.102.4.303$320,2010$.

[34] Päivi-Sisko Eerola, \& Tuomas Eerola, "Extended music education enhances the quality of school life," Music Education Research, vol. 16, no. 1, pp. 88-104, DOI: 10.1080/14613808.2013.829428, 2014.

[35] J. Park, \& J. Lee, "School-level determinants of teacher collegial interaction: Evidence from lower secondary schools in England, Finland, South Korea, and the USA," Teaching and Teacher Education, vol. 50, pp. 24-35, 2015.

[36] J. Yoon, \& T. Järvinen, "Are model PISA pupils happy at school? Quality of school life of adolescents in Finland and Korea," Comparative Education, vol. 52, no. 4, pp. 427-448, 2016.

[37] S.S. Lee, B.J. Fraser, \& D.L. Fisher, "Teacher-student interactions in Korean High school science classrooms," International Journal of Science and Mathematics Education, vol. 1, pp. 67-85 https://doi.org/10.1023/A:1026191226676, 2003. 
[38] N. Park, "Life satisfaction among Korean children and youth: A developmental perspective," School Psychology International, vol. 26, pp. 209-223, 2005.

[39] D. H. Kim, \& J. H. Kim, "Social relations and school life satisfaction in South Korea," Social Indicators Research, vol. 112, no. 1, pp. 105-127, doi:10.1007/s11205-012-0042-8, 2013.

[40] D. W. Jeong, H. J. Lee and S. K. Cho, "Education decentralization, school resources, and student outcomes in Korea," International Journal of Educational Development, vol. 53, pp. 12-27, 2017.

[41] P. Deters, "Comparing the experiences and needs of postsecondary international students from China and South Korea", College Quarterly, vol. 18, no. 1, [Online] Available at: http://collegequarterly.ca/2015-vol18-num01winter/index.html, 2015.

[42] U. Bronfenbrenner, "The ecology of human development," Cambridge, MA: Harvard University Press, 1981.

[43] G. Hofstede, B. Neuijen, D. D.Ohavy, \& G. Sanders, "Measuring organizational cultures-A qualitative and quantitative study across 20 cases," Administrative Science Quarterly, vol. 35, pp. 286-316, 1990.

[44] P. Linnakylä, ve V. Brunell, "Quality of school life in The Finnish And Swedish speaking schools in Finland," in M. Binkley, K. Rust ve T. Williams (Eds.) Reading Literacy In An International Perspective, 203-217, U.S. Department of Education Office of Educational Research and Improvement NCES 97-875.1996.

[45] T.Williams, and M. Batten, "The quality of school life. ACER Research Monograph," no. 12, Hawthorn, Vic.: ACER, 1981.

[46] M. Sar1, E. Ötünç ve H. Erceylan, "Liselerde okul yaşam kalitesi: Adana İli Örneği," Kuram ve Uygulamada Eğitim Yönetimi, vol. 50, pp. 297-320, 2007.

Int. J. Eval. \& Res. Educ. Vol. 9, No. 1, March 2020: 100 - 108 